\title{
EXPERIMENTALWORKS
}

UDC 577.218+616.65

doi: https://doi.org/10.15407/ubj92.01.005

\section{PATTERN OF EXPRESSION OF IMMUNE- AND STROMA-ASSOCIATED GENES IN BLOOD OF MICE WITH EXPERIMENTAL B16 MELANOMA}

G. V. GERASHCHENKO ${ }^{\bowtie}$, I. M. VAGINA, Yu. V. VAGIN, V. I. KASHUBA

Institute of Molecular Biology and Genetics, National Academy of Sciences of Ukraine, Kyiv;

\e-mail: g.v.gerashchenko@imbg.org.ua

Received: 30 May 2019; Accepted: 29 November 2019

The interaction between malignant and stromal cells represents a major cross-talk pathway upon carcinogenesis. Cellular elements of the reactive tumor stroma are a heterogeneous population which are represented specifically by cancer-associated fibroblasts (CAFs) and tumor-associated macrophages (TAM). It is not known whether expression of CAF- and TAM-associated genes could be detected in the peripheral blood of cancer patients to monitor a course of disease. The aim of the study was to assess the relative expression (RE) of cancer-related genes in peripheral blood of mice with experimental melanoma. Quantitative PCR was used to determine RE of 15 genes in the blood of C57BL/6j control mice and mice with injected B16 melanoma cells. The Kruskal-Wallis and the Fischer exact tests with correction on multiple comparisons, according to the Benjamini-Hochberg procedure with FDR $=0.2$ were used for statistical analysis. Analysis of 15 immune and stromal markers RE showed differentiated expression of several CAF and TAM markers in mice with experimental melanoma in comparison with the control animals. Thus, CAF markers Acta2, Cxcl14, Fap and TAM markers Cd68, Ccl22 and Ccl17 were significantly upregulated, while Cd4, Cd3 were downregulated. This, together with increased expression of Cox-2 suggested a stable immunosuppressive state of mice with experimental melanomas. The results of the study showed that potential markers of cancer-associated fibroblasts and tumor-associated macrophages in peripheral blood of mice with experimental melanoma could be used for non-invasive detection of melanoma cell progression.

Ke ywords: melanoma, relative gene expression, cancer-associated genes, cancer-associated fibroblasts, tumor-associated macrophages.

$\mathrm{T}$ he interaction between cancerous and stromal cells represent a major cross-talk pathway upon carcinogenesis, influencing tumor growth and metastasizing [1, 2]. Cellular elements of the reactive tumor stroma are a heterogeneous population which are represented by fibroblasts, cancer-associated fibroblasts (CAFs), macrophages, tumor-associated macrophages (TAM), pericytes, endothelial cells, mesenchymal stem cells, dendritic cells and also other cells of the immune system, such as T-lymphocytes (Th1, Th2, Th17, $\mathrm{T}_{\text {reg }}$ ), B-cells, eosinophils, basophils, neutrophils, NK-cells, etc. [3-6]. The major focus in the studies on reactive tumor stroma is aimed at the identification of the CAFs and analysis of their features, due to the fact, that they interact directly with tumor cells, regulating tumor growth and spread, being the main "sculptor" of the extracellular matrix [7-9]. Unlike normal fibroblasts, CAFs show distinct properties, including increased proliferation rate, enhanced collagen production, secretion of growth factors, stimulation of tumor cell proliferation upon co-culturing [10].

(C) 2020 Gerashchenko G. V. et al. This is an open-access article distributed under the terms of the Creative Commons Attribution License, which permits unrestricted use, distribution, and reproduction in any medium, provided the original author and source are credited. 
Moreover, CAFs differ from normal fibroblasts by expression of a number of specific markers, including Smooth muscle $\alpha$-actin (ACTA2), Vimentin (VIM), Fibroblast specific protein (FSP), Fibroblast activation protein $(F A P)$, Thrombosporin-1 (TSP-1), Tenascin with (TNC), Platelet-derived growth factor- $\alpha$ and $\beta$ (PDGFRA and PDGFRB) receptors and others [11-13]. In addition, they express Matrix metalloproteinases-1 and -3 (MMP1, MMP3), produce collagen and release cytokines $(I L-6, I L-8)$ and chemokines (CXCL12, CXCL8, CXCL14, CCL5, CCL2, CCL7), which leads to the activation of tumor growth and metastasizing [6, 8, 14, 15]. Recent studies showed a regulatory function of CAF in recruiting of monocytes into a tumor development zone, polarization of M2-like macrophages, providing an immunesuppressive role in particular, through the PD-1 axis [16]. Thus, TAMs is yet another important cellular element of the tumor stroma; they are markers of poor prognosis $[17,18]$. TAMs change their metabolism and interact with CAFs; they take part in the reconstruction of the extracellular matrix, which allows both, the local spread of tumor cells and metastasizing (dissemination) [19, 20].

We have to mention that all these findings describe characteristics of solid tumors. It is not known whether expression of CAF- and TAM-associated genes could be detected in the peripheral blood or other biological fluids of cancer patients, to monitor and/or predict a course of the disease as a noninvasive assessment. Therefore, we selected a set of CAF- TAM- and immune-markers to monitor their expression in the blood of animals with experimental melanomas, to identify putative non-invasive markers of tumor growth.

\section{Material and Methods}

Cell line. B16 mouse melanoma cell line was obtained from the Bank of Cell Lines (R. E. Kavetsky IEPOR, NAS of Ukraine). Cells were cultured in a DMEM (Sigma) medium with the addition of $10 \%$ FBS (Sigma), 100 units $/ \mathrm{ml}$ penicillin and $100 \mu \mathrm{g} / \mathrm{ml}$ streptomycin at $37^{\circ} \mathrm{C}$ in a $\mathrm{CO}_{2}$ incubator. Cells were collected after treatment with EDTA/trypsin solution and rinsed in Phosphate-buffered saline (PBS). $2 \times 10^{5}$ of B16 cells were injected into one mouse.

Experimental animals. The cell suspension was injected subcutaneously to the right posterior paw of the adult female mice of a C57BL/6j line. Intact $\mathrm{C} 57 \mathrm{BL} / 6 \mathrm{j}$ females served as a control group. Both the control group and mice with melanomas consisted of five animals. The blood was collected for analysis on the day $19^{\text {th }}$ after melanoma cells were injected. All experiments were carried out, according to European Convention for the Protection of Vertebrate Animals used for experimental and other scientific purposes (Strasbourg, 1986) and followed the rules of handling of experimental animals, approved by Bioethics Committee of IMBG NAS of Ukraine.

Total RNA isolation and cDNA synthesis. $100 \mu \mathrm{l}$ of whole mice blood was thoroughly mixed with $300 \mu 1$ Trizol (Sigma). A total RNA was isolated by Direct-zol RNA MiniPrep total RNA kit (Zymo Research), according to the manufacturer's protocol. The quality and the concentration of the total RNA was determined by the mean of a spectrophotometer (NanoDrop Technologies Inc., USA). cDNA synthesis was performed, using the Maxima First Strand cDNA Synthesis Kit (Thermo Scientific, USA), according to the manufacturer's protocol.

Quantitative PCR ( $q P C R$ ). Relative gene expression (RE) levels were determined, using a 5xHOT FIREPol EvaGreen qPCR Mix Plus (Solis BioDyne, Estonia) and a Bio-Rad CFX96 Real-Time PCR Detection System (USA) with the following program: denaturation at $95^{\circ} \mathrm{C}$ for $12 \mathrm{~min}$, and then 40 cycles $\left(95{ }^{\circ} \mathrm{C}-15 \mathrm{~s}, 60{ }^{\circ} \mathrm{C}-20 \mathrm{~s}, 72{ }^{\circ} \mathrm{C}-20 \mathrm{~s}\right)$ as described earlier [21, 22]. Primers were selected, using the software at https://www.ncbi.nlm.nih.gov/ tools/primer-blast/ and https://primerdepot.nci.nih. gov/ and the site https: //www.origene.com. The reference $T B P$ gene was used to normalize RE levels, using the $2^{-\Delta \mathrm{Ct}}$ and $2^{-\Delta \Delta \mathrm{Ct}}$ methods, as described earlier [22].

Statistical analysis. A statistical analysis was performed using a STATISTICA10 software for the Kruskal-Wallis and the Fischer exact tests with correction on multiple comparisons according to the Benjamini-Hochberg procedure with $\mathrm{FDR}=0.2$ [23].

\section{Results and Discussion}

Experimental tumors, induced after injection of B16 melanoma cells, were detected by palpation. The first tumors were observed at the days $12^{\text {th }}-13^{\text {th }}$. By the day 19, tumors increased to a volume of $4.0 \mathrm{~cm}^{3}$ and reached the maximal allowed size $\left(8.5 \mathrm{~cm}^{3}\right)$ in 28 days. We have chosen the day $19^{\text {th }}$ to perform our experiments.

We assessed the RE levels of 15 immune-associated genes and stromal markers in mouse blood. Namely, there were markers of various populations 
of lymphocytes and tumor-associated macrophages (Cd3, Cd4, Cd8, Cd68, Cd163, Nos2, Ccl17, Ccl22, Ctla4, Cox-2), and also genes characteristic for tumor-associated fibroblasts (Acta2, Fap, Cxcl12, Cxcl14, Hif1a). The levels of the above-mentioned genes RE in mice with experimental melanomas $(\mathrm{T})$ and in control mice (C) were compared using the $2^{-\mathrm{ACt}}$ method (Fig.).

As is seen from Figure, all studied genes showed moderate and low expression levels.

The statistical analysis of RE levels in mice with experimental melanomas and the control animals allowed to identify 6 genes that were significantly up-regulated (Table 1) and 2 genes that were downregulated (Table 2) in animals.

More than two-fold increase/decrease of RE levels was considered as the significant changes. The Cox-2 (Ptgsl) gene, encoding cyclooxygenase 2, showed the highest RE level in peripheral blood of animals with experimental melanomas. It catalyzes the first step of prostaglandin synthesis and is associated with inflammatory diseases and cancer [24]. Cox-2 is expressed in many types of human tumors and its elevated expression is associated with poor prognosis [25, 26].
Table 1. A list of genes, showing increased relative expression in mice with experimental melanomas compared with the control animals

\begin{tabular}{c|c|c|c}
\hline No & Genes & RE, increase & $P$-value \\
\hline 1 & Cox-2 & 22.237 & $P<0.0001$ \\
2 & Ccl22 & 5.486 & $P<0.0001$ \\
3 & Cd68 & 3.165 & $P<0.0001$ \\
4 & Fap & 2.417 & $P<0.001$ \\
5 & Cxcl14 & 2.260 & $P<0.001$ \\
6 & Ccl17 & 2.854 & $P<0.05$ \\
7 & Acta2 & 1.925 & $P=0.055$ \\
\hline
\end{tabular}

Table 2. A list of genes, showing decreased relative expression in mice with experimental melanomas compared with the control animals

\begin{tabular}{c|l|c|c}
\hline No & Genes & RE, decrease & $P$-value \\
\hline 1 & Cxcl12 & 0.235 & $P<0.001$ \\
2 & Cd4 & 0.486 & $P<0.050$ \\
3 & Cd8 & 0.518 & $P=0.055$ \\
4 & Cd163 & 0.540 & $P=0.057$ \\
5 & Cd3 & 0.629 & $P=0.059$ \\
6 & Nos2 & 0.638 & $P=0.059$ \\
\hline
\end{tabular}

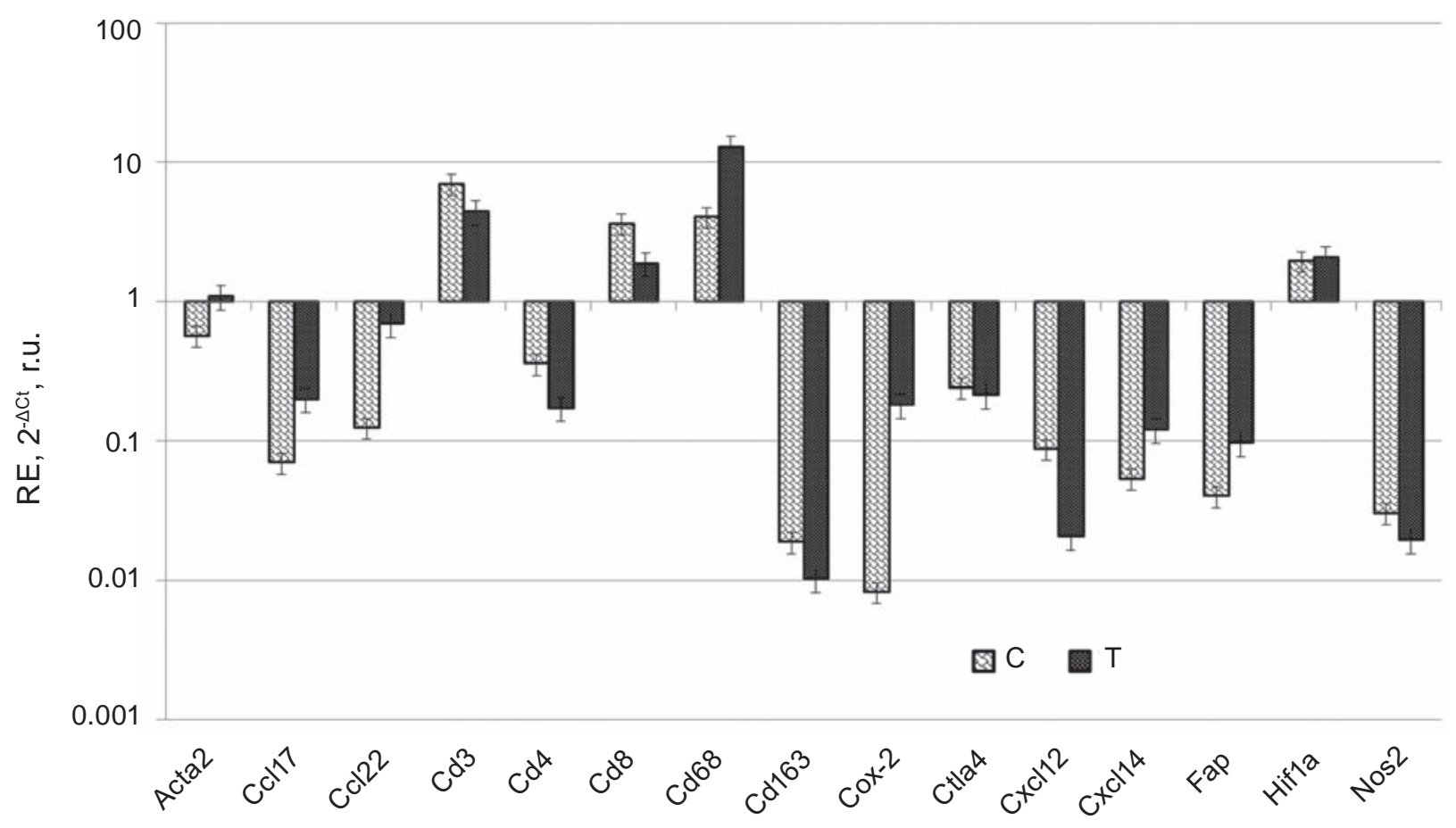

Fig. RE levels of cancer-associated genes in the blood of the control animals $(C)$ and in mice with experimental melanoma $(T)$ 
Cox2 contributes to angiogenesis, tissue invasion and resistance to apoptosis [27, 28]. In addition, COX 2 promotes tumor evasion from immune reaction and cancer resistance to immunotherapy [29]. Increased COX2/PGE2/E-prostaglandin receptor signaling may suppress dendritic cells, natural killer (NK) and T cells, responsible for immunosuppression upon tumor progression [30]. COX2 gene is expressed in both cancerous cells and tumor-associated fibroblasts and macrophages [31, 32]. Our earlier study on prostate cancer showed a positive correlation between RE of COX2, CAF and lymphocytes markers, and correlated negatively with prostate cancer and epithelial cell markers [33]. Noteworthy, Cox-2 relative expression was the highest increase in (more than 20 fold, Table 1,2) indicating the necessity of COX-2 inhibitors using for melanoma treatment in addition to well-known immunotherapy methods.

Noteworthy, Ccl22, Cd68 and Ccl17 were significantly upregulated as well. The RE of Ccl22 gene, encoding immunosuppressive chemokine was increased more than 5 fold. Usually, it is expressed by tumor-associated macrophages [34] and promotes migration of cancerous cells through the CCL22-CCR4 axis [35, 36]. Another marker of tumor-associated macrophages, CD68, showed more than 3-folds increase in mice with experimental melanomas. It is known that CD68 contributes to the establishment of immunosuppressive microenvironment upon tumor progression [37]. The third TAM marker, Ccl17, is closely connected with Ccl22 in the CCL2-CCR2 pathway, which is involved in the regulation of tumor metastasizing [35].

We have revealed earlier the increased RE of other TAM genes Cd14, TIr8 and Il1b in mice with experimental melanomas [38]. This could enhance metastatic spread and immunosuppression [39, 40]. Increased RE of Tlr8 suggests that the special endotype of TAM rising, namely M2c [41].

The other group of genes showing increased $\mathrm{RE}$ in mice with injected melanoma cells consists of CAF markers, namely Cxcl14, Fap and Acta2. It is quite unexpected results, as there are no much data on CAF expression in animal with melanomas. The circulating cancer cells were found in the blood under condition of tumor progression and metastasizing [42, 43], however, the presence of tumor-associated fibroblasts and macrophages in the blood was demonstrated only in several studies $[44,45]$. According to the literature data, this phenomenon can be observed at the later stages of tumor progres- sion, i.e.in advanced cancers. As a rule, circulating CAFs express FAP and ACTA2 simultaneously [44]. In prostate cancer tissue CXCL14 showed the highest RE levels in CAFs, especially at the late stages and upon metastasizing [46]. This suggests that CAFs play a vital role in the dissemination and metastasizing of melanoma cells to other organs and systems, which is not a typical and well-known fact $[44,45]$. It is known that CAFs are a highly abundant and heterogeneous cell population of mesenchymal lineage, which could disseminate to other organs to prepare specific cell niche for metastasizing tumor cells $[47,48]$.

Expression of $C d 3, C d 4, C d 8$ is associated with different $\mathrm{T}$ cell phenotypes, especially, tumorinfiltrating lymphocytes. Decreased expression of these markers in blood indicates reduced immune response [49].

Our data showed that tumor growth was accompanied by CAF and TAM detection in peripheral blood of mice with experimental melanoma. TAM and CAF markers as putative markers of tumor growth and metastasizing could be used for noninvasive detection of melanoma cells.

Conflict of interest. Authors have completed the Unified Conflicts of Interest form at http://ukrbiochemjournal.org/wp-content/uploads/2018/12/ coi_disclosure.pdf and declare no conflict of interest.

Acknowledgments. This work was supported by the Scientific Program of National Academy of Science of Ukraine "Molecular and cell biotechnology for medicine, industry and agriculture" № 41/19.

\section{ПАТЕРНИ ЕКСПРЕСІЇ ІМУНО- ТА СТРОМАЛЬНО-АСОЦЙОВАНИХ ГЕНІВ У КРОВІ МИШЕЙ 3 ЕКСПЕРИМЕНТАЛЬНОЮ МЕЛАНОМОЮ В16}

\section{Г. В. Геращенко ${ }^{\bowtie}$, I. М. Вагіна, Ю. В. Вагін, B. I. Кашуба}

Інститут молекулярної біології і генетики НАН України, Київ; 凶e-mail: g.v.gerashchenko@imbg.org.ua

Клітинні елементи пухлинної строми $\epsilon$ гетерогенною популяцією, представленою, зокрема, пухлиноасоційованими фібробластами (ПАФ) та пухлиноасоційованими макрофагами (ПАМ). Залишається невідомим, чи можна вия- 
вити експресію ПАФ- та ПАМ-асоційованих генів у периферійній крові хворих на рак для моніторингу перебігу захворювання. Метою роботи було оцінити відносну експресію (BE) пухлиноасоційованих генів у периферійній крові мишей 3 експериментальною меланомою. Кількісна ПЛР була використана для встановлення рівнів BE 15 генів у крові інтактних C57BL/6j мишей та мишей із введеними В16 клітинами меланоми. Тести Краскела-Уолліса та точний тест Фішера 3 поправками на множинні порівняння за процедурою Бенжаміні-Хохбера з FDR = 0,2 були використані для статистичного аналізу.

Аналіз ВЕ 15 генів виявив диференційну експресію маркерів пухлиноасоційованих фібробластів (ПАФ) та макрофагів (ПАМ) у групі мишей із введеними клітинами меланоми порівняно 3 контрольними тваринами. Так, рівні експресії маркерів ПАФ Acta2, Cxcl14, Fap та ПАМ маркери Cd68, Ccl22 та Ccl17 були істотно підвищеними, тоді як BE $C d 4, C d 3$ та $C d 8$ були значно зниженими. Ці дані разом 3 підвищеною експресією імуносупресивного маркера Cox-2 свідчив про стійкий імуносупресивний стан експериментальних тварин із введеними клітинами меланоми. Виявлено найбільше посилення ВE Cox-2 (більш ніж у 20 разів), що демонструє необхідність використання COX-2 інгібіторів для лікування меланоми на додаток до відомих імунотерапевтичних методів. Одержані дані вказують, що ПАФ та ПАМ у периферичній крові мишей $з$ експериментальними меланомами можуть бути потенційними маркерами для неінвазивного детектування прогресії пухлин.

К л юч о в і с лов а: меланома, відносна експресія генів, пухлиноасоційовані гени, пухлиноасоційовані фібробласти, пухлиноасоційовані макрофаги.

\section{References}

1. McMillin DW, Negri JM, Mitsiades CS. The role of tumour-stromal interactions in modifying drug response: challenges and opportunities. Nat Rev Drug Discov. 2013; 12(3): 217-228.

2. Belli C, Trapani D, Viale G, D'Amico P, Duso BA, Della Vigna P, Orsi F, Curigliano G. Targeting the microenvironment in solid tumors. Cancer Treat Rev. 2018; 65: 22-32.

3. Bussard KM, Mutkus L, Stumpf K, GomezManzano C, Marini FC. Tumor-associated stromal cells as key contributors to the tumor microenvironment. Breast Cancer Res. 2016; 18(1): 84.

4. Ridge SM, Sullivan FJ, Glynn SA. Mesenchymal stem cells: key players in cancer progression. Mol Cancer. 2017; 16(1): 31.

5. Werb Z, Lu P. The Role of stroma in tumor development. Cancer J. 2015; 21(4): 250-253.

6. Raffaghello L, Dazzi F. Classification and biology of tumour associated stromal cells. Immunol Lett. 2015; 168(2): 175-182.

7. Mezawa Y, Orimo A. The roles of tumor- and metastasis-promoting carcinoma-associated fibroblasts in human carcinomas. Cell Tissue Res. 2016; 365(3): 675-689.

8. Erdogan B, Webb DJ. Cancer-associated fibroblasts modulate growth factor signaling and extracellular matrix remodeling to regulate tumor metastasis. Biochem Soc Trans. 2017; 45(1): 229-236.

9. Alkasalias T, Moyano-Galceran L, ArsenianHenriksson M, Lehti K. Fibroblasts in the tumor microenvironment: shield or spear? Int $\mathrm{J} \mathrm{Mol}$ Sci. 2018; 19(5). pii: E1532.

10. Sazeides C, Le A. Metabolic relationship between cancer-associated fibroblasts and cancer cells. Adv Exp Med Biol. 2018; 1063: 149-165.

11. Patel AK, Vipparthi K, Thatikonda V, Arun I, Bhattacharjee S, Sharan R, Arun P, Singh S. A subtype of cancer-associated fibroblasts with lower expression of alpha-smooth muscle actin suppresses stemness through BMP4 in oral carcinoma. Oncogenesis. 2018; 7(10): 78.

12. Ni WD, Yang ZT, Cui CA, Cui Y, Fang LY, Xuan YH. Tenascin-C is a potential cancerassociated fibroblasts marker and predicts poor prognosis in prostate cancer. Biochem Biophys Res Commun. 2017; 486(3): 607-612.

13. Drev D, Bileck A, Erdem ZN, Mohr T, Timelthaler G, Beer A, Gerner C, Marian B. Proteomic profiling identifies markers for inflammation-related tumor-fibroblast interaction. Clin Proteomics. 2017; 14: 33.

14. Augsten M, Sjöberg E, Frings O, Vorrink SU, Frijhoff J, Olsson E, Borg Å, Östman A. Cancerassociated fibroblasts expressing CXCL14 rely upon NOS1-derived nitric oxide signaling for their tumor-supporting properties. Cancer Res. 2014; 74(11): 2999-3010.

15. Kuzet SE, Gaggioli C. Fibroblast activation in cancer: when seed fertilizes soil. Cell Tissue Res. 2016; 365(3): 607-619. 
16. Gok Yavuz B, Gunaydin G, Gedik ME, Kosemehmetoglu K, Karakoc D, Ozgur F, Guc D. Cancer associated fibroblasts sculpt tumour microenvironment by recruiting monocytes and inducing immunosuppressive PD-1 ${ }^{+}$TAMs. Sci Rep. 2019; 9(1): 3172.

17. Na YR, Je S, Seok SH. Metabolic features of macrophages in inflammatory diseases and cancer. Cancer Lett. 2018; 413: 46-58.

18. Nonnenmacher Y, Hiller K. Biochemistry of proinflammatory macrophage activation. Cell Mol Life Sci. 2018; 75(12): 2093-2109.

19. Netea-Maier RT, Smit JWA, Netea MG. Metabolic changes in tumor cells and tumorassociated macrophages: A mutual relationship. Cancer Lett. 2018; 413: 102-109.

20. Dutsch-Wicherek M, Kazmierczak W. Creation of a suppressive microenvironment by macrophages and cancer-associated fibroblasts. Front Biosci (Landmark Ed). 2013; 18: 1003 1016.

21. Gerashchenko GV, Mankovska OS, Dmitriev AA, Mevs LV, Rosenberg EE, Pikul MV, Marynychenko MV, Gryzodub OP, Stakhovsky EO, Kashuba VI. Expression of epithelial-mesenchymal transition-related genes in prostate tumours. Biopolym Cell. 2017; 33(5): 335-355.

22. Gerashchenko GV, Grygoruk OV, Kononenko OA, Gryzodub OP, Stakhovsky EO, Kashuba VI. Expression pattern of genes associated with tumor microenvironment in prostate cancer. Exp Oncol. 2018; 40(4): 315-322.

23. Benjamini Y, Hochberg Y. Controlling the false discovery rate: a practical and powerful approach to multiple testing. J R Stat Soc. 1995; 57(1): 289-300.

24. Hashemi Goradel N, Najafi M, Salehi E, Farhood B, Mortezaee K. Cyclooxygenase-2 in cancer: A review. J Cell Physiol. 2019; 234(5): 5683-5699.

25. Garg R, Blando JM, Perez CJ, Lal P, Feldman MD, Smyth EM, Ricciotti E, Grosser T, Benavides F, Kazanietz MG. COX-2 mediates pro-tumorigenic effects of $\mathrm{PKC} \varepsilon$ in prostate cancer. Oncogene. 2018; 37(34): 4735-4749.

26. Agrawal U, Kumari N, Vasudeva P, Mohanty NK, Saxena S. Overexpression of COX2 indicates poor survival in urothelial bladder cancer. Ann Diagn Pathol. 2018; 34: 50-55.

27. Gately S, Kerbel R. Therapeutic potential of selective cyclooxygenase-2 inhibitors in the management of tumor angiogenesis. Prog Exp Tumor Res. 2003; 37: 179-192.

28. Qiu X, Cheng JC, Chang HM, Leung PC. COX2 and PGE2 mediate EGF-induced E-cadherinindependent human ovarian cancer cell invasion. Endocr Relat Cancer. 2014; 21(4): 533-543.

29. Liu B, Qu L, Yan S. Cyclooxygenase-2 promotes tumor growth and suppresses tumor immunity. Cancer Cell Int. 2015; 15: 106.

30. Tong D, Liu Q, Wang LA, Xie Q, Pang J, Huang Y, Wang L, Liu G, Zhang D, Lan W, Jiang J. The roles of the COX2/PGE2/EP axis in therapeutic resistance. Cancer Metastasis Rev. 2018; 37(2-3): 355-368.

31. Gan L, Qiu Z, Huang J, Li Y, Huang H, Xiang T, Wan J, Hui T, Lin Y, Li H, Ren G. Cyclooxygenase-2 in tumor-associated macrophages promotes metastatic potential of breast cancer cells through Akt pathway. Int J Biol Sci. 2016; 12(12): 1533-1543.

32. Su CW, Zhang Y, Zhu YT. Stromal COX-2 signaling are correlated with colorectalcancer: A review. Crit Rev Oncol Hematol. 2016; 107: 33-38.

33. Gerashchenko GV, Kononenko OA, Bondarenko YuM, Stakhovsky EO, Kashuba VI. Expression patterns of genes that regulate lipid metabolism in prostate tumors. Biopolym Cell. 2018; 34(6): 445-460.

34. Wang D, Yang L, Yue D, Cao L, Li L, Wang D, Ping Y, Shen Z, Zheng Y, Wang L, Zhang Y. Macrophage-derived CCL22 promotes an immunosuppressive tumormicroenvironment via IL-8 in malignant pleural effusion. Cancer Lett. 2019; 452: 244-253.

35. Maolake A, Izumi K, Shigehara K, Natsagdorj A, Iwamoto H, Kadomoto S, Takezawa Y, Machioka K, Narimoto K, Namiki M, Lin WJ, Wufuer G, Mizokami A. Tumor-associated macrophages promote prostate cancer migration through activationof the CCL22-CCR4 axis. Oncotarget. 2017; 8(6): 9739-9751.

36. Furudate S, Fujimura T, Kambayashi Y, Kakizaki A, Hidaka T, Aiba S. Immunomodulatory effect of imiquimod through CCL22 produced by tumor-associated macrophages in B16F10 melanomas. Anticancer Res. 2017; 37(7): 3461-3471.

37. Takahashi H, Sakakura K, Kudo T, Toyoda M, Kaira K, Oyama T, Chikamatsu K. Cancer-associated fibroblasts promote an 
immunosuppressive microenvironmentthrough the induction and accumulation of protumoral macrophages. Oncotarget. 2017; 8(5): 86338647.

38. Gerashchenko GV, Vagina IM, Vagin YuV, Tkachuk ZYu, Kashuba VI. Expression pattern of immune- and cancer-associated genes in peripheral blood of mice bearing melanoma cells. Biopolym Cell. 2019; 35(4): 313-320.

39. Turrini R, Pabois A, Xenarios I, Coukos G, Delaloye JF, Doucey MA. TIE-2 expressing monocytes in human cancers. Oncoimmunology. 2017; 6(4): e1303585.

40. Tulotta C, Ottewell P. The role of IL-1B in breast cancer bone metastasis. Endocr Relat Cancer. 2018; 25(7): R421-R434.

41. Poh AR, Ernst M. Targeting macrophages in cancer: from bench to bedside. Front Oncol. 2018; 8: 49.

42. García SA, Weitz J, Schölch S. Circulating tumor cells. Methods Mol Biol. 2018; 1692: 213-219.

43. Dasgupta A, Lim AR, Ghajar CM. Circulating and disseminated tumor cells: harbingers or initiators of metastasis? Mol Oncol. 2017; 11(1): 40-61.

44. AoZ, ShahSH, MachlinLM, Parajuli R, MillerPC, Rawal S, Williams AJ, Cote RJ, Lippman ME,
Datar RH, El-Ashry D. Identification of CancerAssociated Fibroblasts in Circulating Blood from Patients with Metastatic Breast Cancer. Cancer Res. 2015;75(22):4681-7.

45. McCarthy JB, El-Ashry D, Turley EA. Hyaluronan, Cancer-Associated Fibroblasts and the Tumor Microenvironment in Malignant Progression. Front Cell Dev Biol. 2018;6:48.

46. Gerashchenko GV, Chashchina LI, Rynditch AV, Kashuba VI. The gene expression pattern as a tool for assessment of components of microenvironment and response to anti-cancer therapy of prostate tumors. Dopov Nac Akad Nauk Ukr. 2019; 4: 86-93.

47. Ogawa M, LaRue AC, Drake CJ. Hematopoietic origin of fibroblasts/myofibroblasts: Its pathophysiologic implications. Blood. 2006;108(9):2893-2896.

48. LeBleu VS, Kalluri R. A peek into cancerassociated fibroblasts: origins, functions and translational impact. Dis Model Mech. 2018; 11(4). pii: dmm029447.

49. Hadrup S, Donia M, Thor Straten P. Effector CD4 and CD8 T cells and their role in the tumor microenvironment. Cancer Microenviron. 2013; 6(2): 123-133. 